\title{
PENINGKATAN KEAKTIFAN DAN HASIL BELAJAR SISWA PADA MATA PELAJARAN PENGETAHUAN BAHAN MAKANAN MELALUI PUZZLE
}

\author{
Heni Purwanti \\ SMK N 4 Yogyakarta \\ henipurwanti_smkn4@yahoo.com
}

\begin{abstract}
Abstrak: Penelitian tindakan kelas ini bertujuan untuk mencari pemecahan masalah terhadap rendahnya aktivitas dan hasil belajar siswa dalam mata pelajaran Pengetahuan Bahan Makanan. Subyek penelitian ini siswa kelas X Kuliner 6 di SMK Negeri 4 Yogyakarta dengan jumlah siswa 36 siswa. Penelitian dilaksanakan dalam dua siklus yang masing-masing siklus terdiri dari 2 kali pertemuan, dengan langkah-langkah penelitian berupa perencanaan, pelaksanaan, pengamatan dan refleksi. Hasil penelitian menunjukkan bahwa, dengan dilaksanakan pembelajaran menggunakan media puzzle dapat meningkatkan aktivitas belajar pada siswa. Pada kondisi awal (prasiklus) nilai rata-rata hasil belajar siswa 60,88 dan baru 38,89 \% siswa mencapai KKM yang ditetapkan sebesar 75. Nilai rata-rata hasil belajar siswa pada siklus I pertemuan 1 sebesar 68,89 dengan ketuntasan belajar 41,67 \% dan pada siklus I pertemuan 2 nilai rata-rata hasil belajar siswa sebesar 72,55 dengan ketuntasan belajar 47,22\%. Pada siklus II pertemuan 1 nilai rata-rata hasil belajar siswa sebesar 88,39 dengan ketuntasan belajar 94,44\% sedang pada siklus II pertemuan 2 nilai rata-rata hasil belajar siswa sebesar 82,63 dengan ketuntasan belajar 97,22 \%. Berdasarkan hasil penelitian, disimpulkan media pembelajaran puzzle dapat meningkatkan aktivitas dan hasil belajar siswa kelas X Kuliner 6 di SMKN 4 Yogyakarta pada mata pelajaran Pengetahuan Bahan Makanan.
\end{abstract}

Kata kunci: Keaktifan, hasil belajar, bahan makanan, puzzle, kuliner

\section{PUZZLE TO IMPROVE STUDENT ACTIVITY AND LEARNING OUTCOMES IN FOOD MATERIALS KNOWLEDGE}

\begin{abstract}
This classroom action research aims to find solutions to problems with low activity and student learning outcomes in the Foodstuff Knowledge subject. The subjects of this study were students of class X Culinary 6 at SMK Negeri 4 Yogyakarta with a total of 36 students. The research was conducted in two cycles, each cycle consisting of 2 meetings, with research steps in the form of planning, implementing, observing and reflecting. The results showed that, by implementing learning using puzzle media, it can increase learning activities in students. In the initial conditions (pre-cycle) the average value of student learning outcomes was 60.88 and only $38.89 \%$ of students reached the KKM which was set at 75. The average value of student learning outcomes in the first cycle of meeting 1 was 68.89 with 41 learning completeness, 67\% and in the first cycle of meeting 2 the average value of student learning outcomes was 72.55 with learning completeness $47.22 \%$. In the second cycle of meeting 1, the average value of student learning outcomes was 88.39 with $94.44 \%$ completeness in learning, while in the second cycle of meeting 2 the average value of student learning outcomes was 82.63 with $97.22 \%$ learning completeness. Based on the results of the study, it was concluded that puzzle learning media could increase the activity and learning outcomes of class X Culinary 6 students at SMKN 4 Yogyakarta on the subject of Foodstuff Knowledge.

Keywords: liveliness, learning outcomes, food ingredients, puzzles, culinary
\end{abstract}

\section{PENDAHULUAN}

Perlu dilakukan pengembangan cara-cara belajar yang efektif untuk memperbaiki kualitas dan mutu pembelajaran, sehingga guru diharapkan selalu melakukan inovasi-inovasi pembelajaran. Dalam bukunya Mgs. Nazaruddin (2007:162) dikatakan menurut J. Drost (1999:2) bahwa pembelajaran merupakan usaha yang dilakukan untuk menjadikan orang lain belajar. Sedangkan Sardiman mengatakan pembelajaran sebagai suatu aktifitas guna menciptakan kreativitas siswa. Dari kedua pendapat tersebut dapat dikemukakan bahwa proses pembelajaran adalah serangkaian kegiatan yang diusahakan dengan tujuan agar orang (misal guru dan siswa) dapat melakukan aktifitas belajar dan hasil belajar diberikan dalam bentuk nilai 
setelah siswa mengikuti evaluasi setelah pembelajaran materi dilaksanakan.

Pembelajaran merupakan interaksi dua arah dari seorang guru dan siswa, dimana keduanya terjadi komunikasi yang intens dan terarah menuju pada suatu target yang telah ditetapkan sebelumnya. Interaksi atau hubungan timbal balik antara guru dan siswa tidak hanya sekedar hubungan antara guru dengan siswa tetapi berupa interaksi edukatif yang artinya interaksi belajar mengajar pencapaiannya bukan hanya pengajaran melainkan juga pendidikan, (Trianto, 2009:17).

Menurut Sulistyorini (2009:35) mengajar adalah memberikan sesuatu dengan cara membimbing dan membantu kegiatan belajar kepada seorang siswa dalam mengembangkan potensi intelektual (emosional dan spiritual) sehingga potensi-potensi tersebut dapat berkembang secara optimal. Dalam pengertian ini maka aktivitas siswa sangat diperlukan dalam pembelajaran sehingga siswa yang seharusnya banyak aktif dan guru berkewajiban menciptakan suatu iklim belajar yang memungkinkan siswa lebih aktif.

Chauhan (1979:46) dalam bukunya Mgs Nazarudin (2007:35), mengajar adalah upaya dalam memberikan stimulasi, bimbingan dan pengarahan, serta dorongan kepada siswa agar terjadi proses belajar. Dengan demikian dalam mengajar yang penting bukan upaya guru menyampaikan bahan melainkan bagaimana siswa dapat mempelajari bahan sesuai dengan tujuan. Sehingga upaya yang harus dilakukan guru adalah menciptakan serangkaian peristiwa yang dapat mempengaruhi siswa belajar. Dalam kaitannya ini peran guru mengalami pergeseran dari yang semula sebagai satusatunya pemberi informasi menjadi sebagai orang yang bertindak sebagai director and fasilitator of learning yaitu pengarah dan pemberi fasilitas untuk terjadinya proses belajar.

Saat proses pembelajaran berlangsung keaktifan belajar siswa dapat dilihat dari keterlibatan siswa dalam proses belajar mengajar yang beraneka ragam seperti saat mendengarkan penjelasan guru, diskusi, membuat laporan pelaksanaan tugas dan sebagainya. Menurut Sardiman (2009: 95) menyatakan bahwa setiap orang yang belajar harus aktif sendiri, sehingga proses pembelajaran tidak akan terjadi tanpa ada aktivitas.
Belajar aktif diharapkan pembelajaran akan terasa lebih cepat, menyenangkan, mendukung, tidak membosankan dan diharapkan lebih menarik. Dalam bukunya Mel Silberman, (2007: xxii) dikatakan yang paling penting dalam pembelajaran aktif adalah siswa perlu melakukan, memecahkan masalah sendiri, menentukan contoh-contoh, mencoba ketrampilan-ketrampilan dan melakukan tugastugas yang tergantung pada pengetahuan yang telah mereka miliki atau yang harus mereka capai.

B. Diedrich dalam bukunya Sardiman (2009 : 100-101) membagi kegiatan belajar siswa dalam 8 kelompok, yaitu: 1. Visual activities (kegiatan-kegiatan visual) seperti membaca, mengamati eksperimen, demonstrasi, pameran, dan mengamati orang lain bekerja atau bermain; 2. Oral Activities (kegiatan-kegiatan lisan) seperti mengemukakan suatu fakta, menghubungkan suatu kejadian, mengajukan pertanyaan, memberi saran, mengemukakan pendapat, wawancara, diskusi, dan interupsi; 3. Listening Activities (kegiatan-kegiatan mendengarkan) seperti mendengarkan uraian, percakapan, diskusi, musik, pidato, dan sebagainya; 4. Writing activities (kegiatan-kegiatan menulis) seperti menulis cerita karangan, laporan, tes, angket, menyalin, dan sebagainya; 5. Drawing activities (kegiatan-kegiatan menggambar) seperti menggambar, membuat grafik, peta, diagram, pola, dan sebagainya; 6. Motor activities (kegiatan-kegiatan motorik) seperti melakukan percobaan, membuat konstruksi, model bermain, berkebun, memelihara binatang, dan sebagainya; 7. Mental activities (kegiatan-kegiatan mental) seperti merenungkan, mengingat, memecahkan masalah, menganalisis, melihat hubungan, mengambil keputusan, dan sebagainya; 8 . Emotional activities (kegiatan-kegiatan emosional) seperti menaruh minat, merasa bosan, gembira, berani, tenang, gugup, dan sebagainya.

Berdasarkan dari pendapat ahli di atas, dalam penelitian ini yang menjadi indikator aktivitas adalah : 1. Aktivitas visual (visual activities) seperti membaca, menulis, melakukan eksperimen dan demonstrasi; 2 . Aktivitas lisan (oral activities) seperti bercerita, tanya jawab, dan diskusi; 3 . Aktivitas mendengarkan (listening activities) seperti mendengarkan penjelasan guru, ceramah, pengarahan; 4. Aktivitas menulis (writting 
activities) seperti mencatat materi, menjawab pertanyaan tertulis; 5. Aktivitas emosional (Emotional activities) seperti menaruh minat, merasa bosan, gembira, berani, tenang, gugup; 6. Aktivitas motorik (motor activities) seperti bermain puzzle; 7. Aktivitas mental seperti : mengingat materi, memecahkan masalah dan mengambil keputusan.

Hasil belajar bukan hanya berupa penguasaan pengetahuan, tetapi juga kecakapan dan ketrampilan dalam melihat, menganalisis dan memecahkan masalah, membuat rencana dan mengadakan pembagian kerja (Syaiful Sagala, 2008: 78). Dengan demikian aktivitas dan hasil belajar dari kegiatan belajar mendapatkan penilaian. Penilaian tidak hanya dilakukan secara tertulis tetapi juga secara lesan dan penilaian akan perbuatan atau sikap siswa selama melakukan proses pembelajaran. Hasil belajar yang baik, akan diperoleh melalui kegiatan belajar yang baik, dan kegiatan belajar yang baik akan memberi hasil yang baik pula. Hasil belajar yang baik akan menggambarkan mutu pendidikan yang baik.

Menurut Suharsimi Arikunto, hasil belajar adalah merupakan sesuatu yang diperoleh siswa dalam proses pembelajaran yang ditunjukkan oleh adanya perubahan tingkah laku dalam bentuk pengalaman dan latihan. Sehingga hasil belajar atau prestasi belajar merupakan perilaku yang diperoleh siswa setelah mengalami aktivitas belajar. Aspekaspek perubahan perilaku tersebut tergantung yang dipelajari oleh siswa, jika siswa mempelajari pengetahuan tentang konsep, maka perubahan perilaku yang diperoleh adalah berupa penguasaan konsep.

Tujuan utama pembelajaran dengan media belajar puzzle adalah siswa belajar dengan bermain dengan suasana menyenangkan, gembira sehingga proses pembelajaran tidak membosankan dan pada akhirnya tercapai tujuan pembelajaran. Media pembelajaran adalah segala sesuatu yang dapat digunakan untuk menyalurkan pesan serta apat merangsang fikiran. Salah satu media pembelajaran yang digunakan dalam penelitian ini adalah dengan menggunakan media pembelajaran berupa puzzle pada kompetensi dasar memahami bagian-bagian tubuh sapi dan hasil olahannya. Puzzle adalah permainan menyusun gambar yaitu dengan cara potongan-potongan gambar yang diacak terlebih dahulu dan kemudian potongan-potongan gambar tersebut disusun kembali dalam sebuah bingkai sesuai gambar utuh yang di harapkan. Permainan Puzzle diharapkan dapat meningkatkan keaktifan dan prestasi belajar siswa, karena dengan media puzzle proses pembelajaran akan menyenangkan siswa. Bermain Puzzle akan membantu siswa untuk berlatih memecahkan masalah dengan suasana yang menyenangkan. Permainan ini akan membantu siswa untuk berfikir dari berbagai sudut pandang dalam menyelesaikan suatu masalah (Rizki Siddiq Nugraha, 2016). Selain itu bermain puzzle juga memerlukan kesabaran dan ketrampilan sosial dalam berinteraksi dengan orang lain (teman) sehingga terwujud proses pembelajaran yang aktif sehingga dapat meningkatkan prestasi belajar siswa.

Gambar dibawah ini adalah gambar sapi dengan potongan tubuh sapi yang digunakan sebagai media pembelajaran Pengetahuan Bahan Makanan pada materi daging dan hasil olahannya. Gambar sapi tersebut dipotongpotong terlebih dahulu sesuai nama potongan sehingga menjadi sebuah media pembelajaran puzzle. Kemudian siswa bertugas menyusun potongan tersebut sehingga menjadi gambar sapi yang utuh.

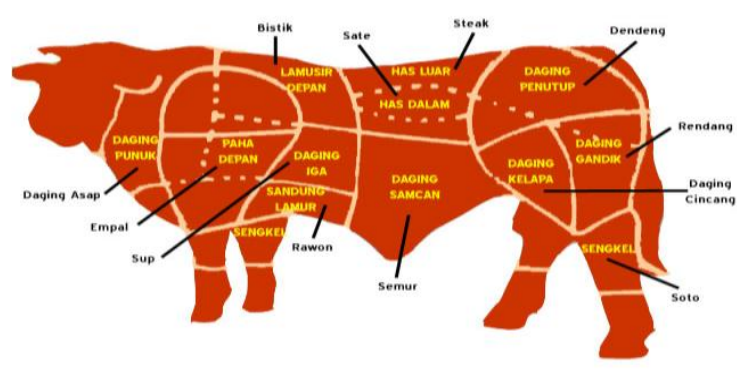

Gambar 1. potongan tubuh sapi

Rumusan masalah yang diajukan pada penelitian kali ini adalah apakah media pembelajaran Puzzle dapat meningkatkan keaktifan dan hasil belajar siswa pada pembelajaran Pengetahuan Bahan Makanan kelas X Kuliner6 di SMK Negeri 4 Yogyakarta. Sedangkan tujuan penelitian ini adalah untuk mengetahui keaktifan dan prestasi belajar siswa pada pembelajaran Pengetahuan Bahan Makanan kelas X Kuliner 6 di SMK Negeri 4 Yogyakarta dengan menggunakan media pembelajaran Puzzle.

\section{METODE PENELITIAN}

Sumber data penelitian tindakan kelas dengan judul Puzzle untuk meningkatkan keaktifan dan hasil belajar siswa X kuliner 6 di SMK Negeri 4 Yogakarta tahun pelajaran 
2019/2020, melibatkan 36 siswa, terdiri dari 10 siswa laki-laki dan 26 siswa perempuan, dengan pengumpulan data yang meliputi : 1 . Dokumen hasil belajar siswa; 2. Dokumen aktivitas siswa selama pembelajaran; 3. Dokumen media pembelajaran Puzzle. Teknik pengumpulan data dengan tes formatif dan observasi/ pengamatan selama proses pembelajaran berlangsung dengan menggunakan media pembelajaran Puzzle.

Pembelajaran dengan media pembelajaran Puzzle dilaksanakan dengan cara membentuk kelompok belajar siswa, dimana setiap kelompok terdiri dari 4 siswa dengan satu ketua kelompok. Ketua kelompok diharapkan mampu membantu kesulitan belajar teman dalam kelompoknya. Pada awal pembelajaran ketua kelompok mencoba menyusun puzzle dan salah satu teman menghitung waktu yang dibutuhkan untuk menyelesaikan susunan puzzle dengan tepat dan baik.Kemudian dua teman yang lain memperhatikan susunan puzzle tersebut sudah tepat atau belum, dan hal tersebut dilakukan bergantian sehingga semua siswa mendapatkan giliran menyusun puzzle dengan tepat dan baik. Pertemuan berikutnya dilanjutkan dengan menyebutkan nama potongan tubuh sapi dan ciri potongan tersebut. Pertemuan terakhir siswa diberikan pekerjaan dengan menyebutkan hasil olahan yang cocok untuk potongan tersebut.Adapun kerangka berfikir secara skematis dapat dilihat sebagai berikut:

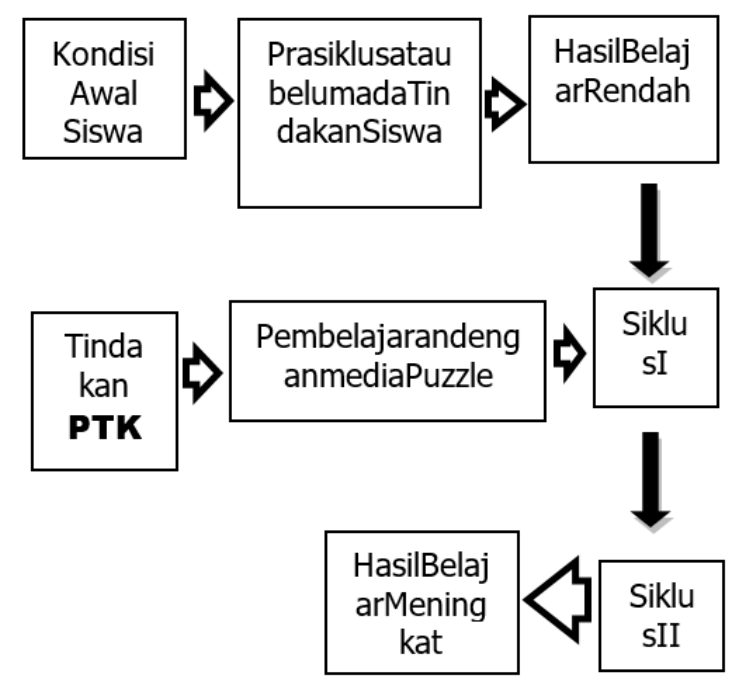

Gambar 2. Kerangka Berfikir PTK

Berikut rancangan penelitian tindakan kelas yang dilakukan oleh peneliti yang dengan mengikuti model yang dikembangkan oleh Kemmis dan Mc Taggart (1990: 14), yang dijabarkan oleh Suharsimi Arikunto (2006: 16).

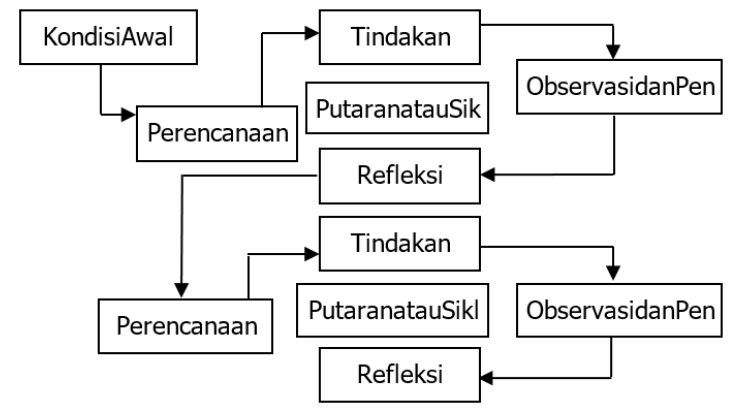

Gambar 3. Siklus PTK yang dikembangkan Kemmis dan Mc Taggart (1990: 14).

Berkaitan dengan gambar siklus PTK di atas, maka dalam penelitian yang akan dilaksanakan dalam 2 siklus dengan dua kali pertemuan setiap siklusnya. Pada setiap siklusnya mencakup 4 kegiatan adalah : (1) Perencanaan, (2) pelaksanaan, (3) pengamatan/ observasi, (4) refleksi.

\section{HASIL DAN PEMBAHASAN \\ Kondisi Awal (Prasiklus)}

Kondisi awal (prasiklus) adalah kondisi pembelajaran yang berpusat pada guru, yaitu guru menerangkan materi daging dan olahannya dengan dibantu menampilkan materi dalam bentuk powerpoint, siswa mendengarkan dan mencatat materi yang diterangkan oleh guru. Setelah dilaksanakan proses pembelajaran kemudian dilanjutkan dengan penilaian tertulis, dengan hasil belajar / penilaian sebagai berikut : Tabel 1. Rekapitulasi Hasil Belajar Siswa kelas X Kuliner 6 pada prasiklus

\begin{tabular}{clc}
\hline No & \multicolumn{1}{c}{ Uraian } & Hasil Prestasi Belajar Siswa \\
\hline 1 & Nilai rata-rata & 60,88 \\
2 & Tuntas & 14 \\
3 & Belum tuntas & 22 \\
\hline
\end{tabular}

Berdasarkan data dalam tabel 1 nilai ratarata prasiklus adalah 60,88 dan ketuntasan belajar hanya sebesar 38,89\%. Masih ada 61,11\% siswa yang masih berada dibawah KKM yang ditetapkan adalah 75. Dari 36 siswa, terdapat 14 siswa yang sudah mencapai ketuntasan, sedangkan 22 siswa belum tuntas.

\section{Keaktifan dan Hasil belajar pada Siklus I}

Siklus I pada penelitian tindakan kelas ini dilaksanakan pembelajaran dengan menggunakan media puzzle. Pembelajaran dengan materi daging dan hasil olahannya yaitu mempelajari potongan-potongan pada tubuh sapi dengan memasang potongan-potongan tubuh sapi pada puzzle yang sudah disiapkan sambil menyebut nama potongan tersebut. 
Penilaian dilaksanakan oleh teman kelompok dengan menghitung jumlah betul nama potongan yang disebutkan dan waktu yang digunakan untuk menyelesaikan permainan puzzle.
Hasil observasi aktifitas proses pembelajaran siswa yang dilakukan pada siklus I pertemuan 1 dan pertemuan 2, rekapitulasi datanya disajikan pada tabel 2 berikut:

Tabel 2. Keaktifan pada Tindakan Siklus I

\begin{tabular}{llcccccc}
\hline & & \multicolumn{6}{c}{ Hasil Observasi (\%) } \\
\cline { 3 - 8 } No & Aspek yang diobservasi & \multicolumn{3}{c}{ Pertemuan 1 } & \multicolumn{3}{c}{ Pertemuan 2 } \\
\cline { 2 - 7 } & & Baik & Cukup & Kurang & Baik & Cukup & Kurang \\
\hline 1. & Visual activities & - & 100 & - & 22,22 & 22,22 & 55,56 \\
2. & Oral Activities & - & 27,78 & 72,78 & 11,11 & 27,78 & 61,11 \\
3. & Listening Activities & 44,44 & 27,78 & 27,78 & 55,56 & 38,89 & 5,55 \\
4. & Writing Activities & - & 100 & - & 27,78 & 72,22 & - \\
5. & Emotional Activities & 27,78 & 27,78 & 44,44 & 55,56 & 38,89 & 5,55 \\
6. & Motoric Activities & - & - & 100 & 55,56 & 38,89 & 5,55 \\
7. & Mental Activities & - & 22,22 & 77,78 & 22,22 & 38,89 & 38,89 \\
\hline
\end{tabular}

Pada data tabel 2, siklus I pertemuan 1 dibanding dengan pertemuan 2 terjadi kenaikan aktivitas siswa selama proses pembelajaran berlangsung. Pada pertemuan 1 siklus I, keaktifan siswa belum tampak betul perubahannya, hal ini kemungkinan karena siswa masih mencoba menghafalkan namanama potongan tubuh sapi dan masih malu untuk mencoba bermain puzzle. Terlihat ada beberapa siswa yang masihterbiasa dengan pembelajaran yang berpusat pada guru. Mereka menunggu instruksi guru terlebih dahulu, sebelum melaksanakan kegiatan pembelajaran. Dominan guru masih diperlukan untuk mengingatkan atau menginstrusi siswa untuk aktif dalam mengikuti proses pembelajaran.

Pada pertemuan 2 aktivitas siswa yang diharapkan selama proses pembelajaran mulai terlihat, siswa sudah mulai bergantian bermain puzzle sambil menyebutkan nama potongan tubuh sapi, siswa mulai antusias untuk memperbaiki waktu dalam bermain puzzle dan sudah terjadi komunikasi dalam diskusi kelompok walaupun hanya pada beberapa kelompok saja, seperti siswa menanyakan letak potongan puzzle yang tepat. Dapat terlihat siswa dalam satu kelompok konsentrasi untuk menata puzzle sesuai dengan tempatnya, sedangkan siswa yang lain dalam kelompok yang sama konsentrasi mengamati permainan teman dalam kelompoknya sambil juga menghafal letak puzzle dan ada juga yang bertugas mengamati waktu yang digunakan untuk menyelesaikan puzzle.

Setelah dilakukan tindakan dengan menggunakan media pembelajaran puzzle selama proses pembelajaran selanjutnya dilakukan penilaian tertulis dengan memberikan soal kepada setiap siswa untuk dikerjakan secara individu. Pada tabel di bawah ini dapat diketahui hasil penilaian siswa. Siklus I nilai rata-rata hasil belajar siswa sudah mengalami kenaikan jika dibandingkan pada prasiklus, begitu juga antara pertemuan 1 dengan pertemuan 2 sudah terjadi kenaikan nilai rata-rata hasil belajar siswa. Tetapi nilai rata-rata hasil belajar siswa pada siklus I masih dibawah KKM yang ditetapkan sebesar 75. Sehingga penelitian dilanjutkan ke siklus II.

Tabel 3. Rekapitulasi Hasil Belajar Siswa kelas X Kuliner 6 pada Siklus I

\begin{tabular}{clcc}
\hline \multirow{2}{*}{ No } & \multicolumn{2}{c}{ Uraian } & \multicolumn{2}{c}{ Hasil Belajar Siswa } \\
\cline { 3 - 4 } & & Pertemuan 1 & Pertemuan 2 \\
\hline 1 & Nilai rata-rata & 68,89 & 72,55 \\
2 & Nilai tertinggi & 100 & 98 \\
3 & Nilai terendah & 26 & 45 \\
4 & Tuntas & $15(41,67 \%)$ & $17(47,22 \%)$ \\
5 & Belum tuntas & $21(58,33 \%)$ & $19(52,78 \%)$ \\
\hline
\end{tabular}




\section{Keaktifan dan Hasil belajar pada Siklus II}

Proses pembelajaran siklus II dengan materi sifat dan hasil olahan daging sapi, yaitu siswa menyebut sifat dan hasil olahan pada potongan daging sapi. Potongan puzzle yang sudah disiapkan dipresentasikan di depan kelas dengan menyebut sifat dari potongan daging sapidan menyebut hasil olahan yang cocok dengan potongan daging sapi tersebut. Siswa maju presentasi satu persatu dengan membawa potongan puzzle daging sapi, dengan cara menunjukkan potongan tersebut dihadapan teman-teman dikelas dan menyebutkan sifat potongan daging sapi dan hasil olahannya. Siswa dibelakang memperhatikan presentasi teman yang didepan serta memberikan komentar betul atau salah dari presentas tersebut.
Setelah proses pembelajaran berlangsung kemudian dilanjutkan dengan penilaian pembelajaran berupa tes tertulis yang dikerjakan scara individu. Pada siklus II pertemuan 1 dilakukan penilaian tertulis bentuk soal isian dengan materi nama dan sifat daging sapi sedang pada pertemuan 2 dilakukan penilaian dengan dua macam soal yaitu soal pilihan ganda dan isian dengan materi sifat dan hasil olahan daging sapi.

Hasil observasi aktifitas siswa selama proses pembelajaran yang dilakukan pada siklus II pertemuan 1 dan pertemuan 2, rekapitulasi datanya disajikan pada tabel 4 berikut:

Tabel 4. Keaktifan pada Tindakan Siklus II

\begin{tabular}{|c|c|c|c|c|c|c|c|}
\hline \multirow{3}{*}{ No } & \multirow{3}{*}{$\begin{array}{l}\text { Aspek yang } \\
\text { diobservasi }\end{array}$} & \multicolumn{6}{|c|}{ Hasil Observasi (\%) } \\
\hline & & \multicolumn{3}{|c|}{ Pertemuan I } & \multicolumn{3}{|c|}{ Pertemuan II } \\
\hline & & Baik & Cukup & Kurang & Baik & Cukup & Kurang \\
\hline 1. & Visual activities & 72,22 & 22,22 & 5,56 & 83,33 & 16,67 & - \\
\hline 2. & Oral Activities & 94,44 & 2,78 & 2,78 & 88,89 & 11,11 & - \\
\hline 3. & Listening Activities & 83,33 & 11,11 & 5,56 & 94,44 & 5,56 & - \\
\hline 4. & Writing Activities & 83,33 & 11,11 & 5,56 & 94,44 & 5,56 & - \\
\hline 5. & Emotional Activities & 83,33 & 11,11 & 5,56 & 97,22 & 2,78 & - \\
\hline 6. & Motoric Activities & 100 & - & - & 100 & - & - \\
\hline 7. & Mental Activities & 94,44 & 5,56 & - & 94,44 & 5,56 & - \\
\hline
\end{tabular}

Berdasar data tabel 4 terlihat pada setiap aktivitas siswa yang diobsevasi selama proses pembelajaran berlangsung, telah terjadi peningkatankeaktifan siswa yang termasuk dalam kategori baik. Pada siklus II sebagian besar siswa sudah menyesuaikan dengan media puzzel. Komunikasi antar siswa sudah berjalan dengan baik disetiap kelompok, siswa terlihat gembira saat melakukan permainan puzzle.
Kondisi ini terjadi karena pembelajaran dengan media puzzle sangat menyenangkan dan penuh tantangan, serta dapat mengurangi rasa canggung dan takut selama proses pembelajaran berlangsung. Siswa lebih bebas melakukan aktivitas yang menyebabkan suasana pembelajaran menjadi menyenangkan. Rekapitulasi hasil belajar siswa pada siklus II dikemukakan pada tabel 5 berikut ini :

Tabel 5 Rekapitulasi Hasil Belajar Siswa kelas X Kuliner 6 pada Siklus II

\begin{tabular}{clcc}
\multirow{2}{*}{ No } & \multirow{2}{*}{ Uraian } & \multicolumn{2}{c}{ Hasil Belajar Siswa } \\
\cline { 3 - 4 } & & Pertemuan 1 & Pertemuan 2 \\
\hline 1 & Nilai rata-rata & 88,39 & 82,63 \\
2 & Nilai tertinggi & 100 & 90 \\
3 & Nilai terendah & 60 & 70 \\
4 & Tuntas & $34(94,44 \%)$ & $35(97,22 \%)$ \\
5 & Belum tuntas & $2(5,56 \%)$ & $1(2,78 \%)$ \\
\hline
\end{tabular}

Evaluasi yang dilakukan siklus II, pada pertemuan 1 nilai rata-rata yang diperoleh 88,39 lebih tinggi sebesar 5,76 dibandingkan dengan nilai rata-rata pada pertemuan 2 yang hanya sebesar 82,63. Hal ini kemungkinan terjadi, karena kesulitan materi yang berbeda antara pertemuan 1 dengan peertemuan 2 . Dibandingkan dengan siklus I, pada siklus II sudah terjadi kenaikan nilai rata-rata yang cukup tinggi. Pada siklus II ini nilai rata-rata sudah lebih 
dari KKM yang ditentukan. Walaupun nilai ratarata sudah melebihi KKM tetapi terlihat pada pertemuan 1masih ada nilai evaluasi 2 siswa atau $6,45 \%$ dari 36 siswa belum tuntas, dan pada pertemuan 2 ada 1 siswa atau sebesar $2,78 \%$ dari 36 siswa yang belum tuntas KKM. Dilihat dari siswa yang belum KKM, pada siklus II pertemuan 1 dan 2 ada 1 siswa yang belum mencapai ketuntasan pada pertemuan 1 maupun pada pertemuan 2. Berdasarkan pencermatan dan tindak lanjut, 1 siswa tersebut memang mengalami hambatan dalam proses pembelajaran, siswa tersebut tidak dapat konsentrasi selama pembelajaran karena mengalami kesulitan dalam bergaul dengan teman-temannya, sehingga merasa canggung dalam bermain puzzle dengan teman-temannya.

\section{SIMPULAN DAN SARAN}

Berdasarkanuraian di atas yang diperoleh dari pelaksanaan tindakan kelas, maka dapat disimpulkan bahwa, pelaksanaan pembelajaran dengan menggunakan media puzzle dapat meningkatkan keaktifan belajar siswa yang meliputi visual activities, oral activities, listening activities, writing activities, motor activities, mental activitiesdan emotional activities.Pelaksanaan pembelajaran dengan menggunakan media puzzle dapat meningkatkan hasil belajar yang meliputi nilai rata-rata kelas dan pencapaian standar ketuntasan minimal pembelajaran Pengetahuan Bahan Makanan sebesar 75.

Adapun saran yang peneliti harapkan kepada sesama pendidik jurusan kuliner pada khususnya dan semua pendidik pada umumnya, dalam pelaksanaan proses pembelajaran diharapkan bagi pendidik untuk mengembangkan media pembelajaran yang digunakan dalam proses pembelajaran sehingga dapat membantu siswa untuk memahami materi pembelajaran.

\section{DAFTAR PUSTAKA}

AM., Sardiman,(2009).Interaksi dan Motifasi Belajar Mengajar, Jakarta: Rajawali.

Arikunto, Suharsimi, (2010).Penelitian Tindakan Kelas, Jakarta: Bumi Aksara.

M., Silberman. (2007). Active Learning: 101 Strategi Pembelajaran Aktid (terjemahan cetakan ke-6),Yogyakarta: Pustakan Insani Madani dan YAPPENDIS.

Nazarudin, Mgs. (2007). Manajemen Pembelajaran Implementasi Konsep, Karaktristik dan Metodologi Pendidikan Agama Islam di Sekolah Umum, Yogyakarta: Teras.

Sagala, Syaiful. (2008). Konsep dan Makna Pembelajaran, Bandung, Alfabeta

Sulistyorini, 2009, Evaluasi Pendidikan Dalam Meningkatkan Mutu Pendidikan, Yogyakarta: Teras.

Trianto.(2009). Mendesain Model Pembelajaran Inovatif Progresif, Jakarta: Kencana.

Rizki Siddiq Nugraha. (2016). Media Pembelajaran, http://https://www.tintapen didikanindonesia.com/2016/06/media-pe mbelajaran-puzzle_5.html diakses tanggal 1 Desember 2019 